\title{
Editorial
}

Pathobiology

Pathobiology 2008;75:61-62

DOI: 10.1159/000123843

\section{Translational Research in Breast Cancer}

\author{
Bettina Borisch \\ Institute of Social and Preventive Medicine, University of Geneva, CMU, Geneva, Switzerland
}

Recent advances in our knowledge of the molecular and cellular biology of cancer have emerged from the laboratory. The resulting challenge has been how to turn these advances in knowledge into advances in the clinic as rapidly and practically as possible.

For breast cancer, the challenge is even more important as the incidence and total burden of disease is increasing rapidly worldwide. Even if the number of breast cancer survivors is increasing, the harm and distress associated with the diagnosis and treatment of breast cancer challenge both bench-orientated research and public health work. Knowing very well that breast cancer is not one single disease, the scientific community strives to obtain biological information of different types of breast cancer linked to clinical data such as overall survival, disease-free survival or quality of life. In addition, among the well-categorized histological subtypes and the groupings delivered by receptor status, research tries to further investigate the existence of associations between well-established and newly recognized biological and phenotypic features involved in tumor prognosis [1]. Another way of tackling the complexity of breast cancer was to utilize gene expression profiling technology [2]. Gene expression measurements from breast cancer have almost become clinical predictive tools to identify tumor subtypes, patients showing poor/good prognosis and patients likely to have disease recurrence. This evolution in the laboratory and clinical research has stimulated an interest in potential results that could be directly used in the daily routine. This also explains the interest of a larger public in these issues; breast cancer activists are willing to take up a role in the creation of biological and clinical databases. Patients are asked to lobby for and help in clinical studies. On the other hand, the access to human tissues is only possible via the patient. The discussion around the Human Tissue Act in Britain may serve as one example [3].

Microarray analysis of breast cancer has discovered (or rediscovered) the basal-like tumors; their importance in terms of therapy and diagnosis as well as their relation to so-called triple negative are described in the review by Rakha et al. [4]. Basal-like tumors frequently carry BRCA1 mutations. BRCA1 inactivation would lead to a stem celllike phenotype. But what is the impact of the cancer stem cell in breast cancer? In the last 10 years, cancer stem cells have been isolated from many tumors including breast, colon, pancreas, lung, brain, head and neck to mention only some. What is the role of the cancer stem cell for breast cancer? Is there a link to the above-mentioned basal-like phenotype? The work of Charaffe-Jauffret et al. [5] provides insights into these and other questions, such as: What is the role of cancer stem cells for the metastatic potential and prognosis of breast cancer? Cells with a stem cell phenotype were found in the circulating tumor cells in the bone marrow. The occurrence of isolated tumor cells is depicted in the work of Riethdorf and Pantel [6]. The authors from the Jules Bordet Institute in Brussels revisit histological grade in the light of the new mo-

\section{KARGER}

Fax +41613061234

E-Mail karger@karger.ch

www.karger.com (c) 2008 S. Karger AG, Basel

$1015-2008 / 08 / 0752-0061 \$ 24.50 / 0$

Accessible online at:

www.karger.com/pat
Prof. Bettina Borisch

Institute of Social and Preventive Medicine

University of Geneva, CMU, 1, rue Michel-Servet

$\mathrm{CH}-1211$ Geneva 4 (Switzerland)

Tel. +41 22379 5954, Fax +4122379 5912, E-Mail bettina.borisch@medecine.unige.ch 
lecular knowledge [7]. Furthermore, Tan and Reis-Filho [8] show the possibilities of comparative genomic hybridization arrays in targeted therapy decision. Bertheau et al. [9] discuss p53 expression in relation to therapy. In hereditary breast cancer, there are not only $B R C A 1$ but also $B R C A 2$ tumors and Palacios et al. [10] discuss their characteristics. There is a word of caution from Srour et al. [11], who have performed a meta-analysis of gene-arraying studies done on human materials. They conclude that there is still more effort needed in the quality control of such studies.
This issue provides the reader with the newest results from genetics over the genomic expression profiling of new types of breast cancer to the importance of isolated circulating tumor cells for prognosis and management of breast cancer patients. This collection contains up-todate information to all gynecologists, senologists, breast surgeons, oncologists, pathologists, breast cancer nurses, basic researchers in the field and a larger audience in the medical community interested in the most recent updates in breast cancer.

\section{References}

-1 Florena AM, Tripodo C, Guarnotta C, Ingrao S, Porcasi R, Martorana A, Lo Bosco G, Cabibi D, Franco V: Associations between Notch-2, Akt-1 and HER2/neu expression in invasive human breast cancer: a tissue microarray immunophenotypic analysis on 98 patients. Pathobiology 2007;74:317-322.

$\checkmark 2$ Perou CM, Sorlie T, Eisen MB, van de Rijn M, Jeffrey SS, Rees CA, Pollack JR, Ross DT, Johnsen H, Akslen LA, Fluge O, Pergamenschikov A, Williams C, Zhu SX, Lønning PE, Børresen-Dale AL, Brown PO, Botstein D: Molecular portraits of human breast tumours. Nature 2000;406:747-752.

$>3$ Borisch B: Tissue banking in a regulated environment: does this help the patient? Pathobiology 2007;74:223-226.
4 Rakha EA, Reis-Filho JS, Ellis IO: Impact of basal-like breast carcinoma determination for a more specific therapy. Pathobiology 2008;75:95-103.

5 Charafe-Jauffret E, Monville F, Ginestier C, Dontu G, Birnbaum D, Wicha MS: Cancer stem cells in breast: current opinion and future challenges. Pathobiology 2008;75:7584.

6 Riethdorf S, Pantel K: Disseminated tumor cells in bone marrow and circulating tumor cells in blood of breast cancer patients: current state of detection and characterization. Pathobiology 2008;75:140-148.

7 Ignatiadis M, Sotiriou C: Understanding the molecular basis of histologic grade. Pathobiology 2008;75:104-111.
-8 Tan DSP, Reis-Filho JS: Comparative genomic hybridisation arrays: high-throughput tools to determine targeted therapy in breast cancer. Pathobiology 2008;75:63-74.

$\checkmark$ Bertheau P, Espié M, Turpin E, Lehmann J, Plassa LF, Varna M, Janin A, de Thé H: TP53 status and response to chemotherapy in breast cancer. Pathobiology 2008;75:132139.

10 Palacios J, Robles Frías MJ, Castilla MA, López-García MA, Benítez J: The molecular pathology of hereditary breast cancer. Pathobiology 2008;75:85-94.

11 Srour N, Reymond MA, Steinert R: Lost in translation? A systemic database of gene expression in breast cancer. Pathobiology 2008;75:112-118. 